\title{
Seroprevalence of Toxoplasma gondii and Neospora spp. Infections in Arab Horses, Southwest of Iran
}

\author{
Mehdi Tavalla ${ }^{1,2,}$; Mohammad Sabaghan ${ }^{1}$; Rahman Abdizadeh ${ }^{3}$; Shahram Khademvatan ${ }^{4}$; \\ Abdollah Rafiei ${ }^{1,2}$; Anahita Razavi Piranshahi ${ }^{1}$ \\ ${ }^{1}$ Department of Medical Parasitology, Faculty of Medicine, Ahvaz Jundishapur University of Medical Sciences, Ahvaz, IR Iran \\ ${ }_{2}^{2}$ Infectious and Tropical Diseases Research Center, Ahvaz Jundishapur University of Medical Sciences, Ahvaz, IR Iran \\ ${ }^{3}$ Department of Medical Parasitology and Mycology, Faculty of Medicine, Shahrekord University of Medical Sciences, Shahrekord, IR Iran \\ ${ }^{4}$ Department of Medical Parasitology, Urmia University of Medical Sciences, Urmia, IR Iran \\ ${ }^{*}$ Corresponding author: Mehdi Tavalla, Department of Medical Parasitology, Ahvaz Jundishapur University of Medical Sciences, Ahvaz, IR Iran. P. O. Box: 61357-33118, Tel:+98-6113367543, \\ Fax:+98-6113367545, E-mail: am.tavalla@gmail.com
}

Received: September 19, 2013; Revised: April 19, 2014; Accepted: November 2, 2014

\begin{abstract}
Background: Because of the economic importance of the Arab race horses and also the role of Toxoplasma gondii and Neospora spp. in abortion and reproductive failure of these animals, we decided to perform this study.

Objectives: We designed this study to investigate the seroprevalence of anti-Toxoplasma gondii and anti-Neospora spp. antibodies in Arab horses from 12 cities of Khuzestan province in southwest of Iran.

Materials and Methods: From October 2009 to March 2011, a total of 235 blood samples were collected from jugular veins of Arab horses of different ages and genders from 12 cities of Khuzestan province. All the sera were tested for anti-Toxoplasma antibodies using the modified agglutination test (MAT) and the existence of anti-Neospora antibodies were tested using N-MAT for Neospora spp.

Results: According to the MAT results, antibodies to T. gondii were found in 114 (48.5\%) of 235 sera with titers of 1:20 in 84, 1:40 in 19, 1:80 in four, 1:160 in four, and 1:320 in three horses. According to the N-MAT results, antibodies to Neospora spp. were found in 47 (20\%) of 235 sera with titers of 1:40 in 39,1:80 in five, and 1:160 in three horses. We did not observe any statistically significant differences regarding age groups and genders between seropositive and seronegative horses for Neospora spp. using chi-square $\left(\chi^{2}\right)$ test, but it seemed that antiToxoplasma antibodies were more prevalent in older horses ( $\geq 10$ years old).

Conclusions: The results indicated that Arab horses are exposed to these parasites in southwest of Iran. Further research is required to determine the genomic structures of these parasites in Arab horses in southwest of Iran.
\end{abstract}

Keywords: Toxoplasma gondii; Neospora; Agglutination Tests; horses; Iran

\section{Background}

Toxoplasma gondii and Neospora spp. are obligate, intracellular, coccidian protozoan parasites belonging to the Apicomplexa phylum and are closely related tissue-dwelling protozoan parasites with similarity in morphological and biological characteristics, infecting almost all warmblooded animals $(1,2)$. Antibodies of these parasites have been found in the sera of many species of domestic and wild animals worldwide (3-6). Both parasites have indirect life cycles. Definitive hosts of $T$. gondii are cats and other felids (7). Mainly dogs and perhaps other canids are the definitive hosts of $N$. caninum, but the definitive host of $N$. hughesi is still unknown $(8,9)$. These parasites have a wide range of intermediate hosts including sheep, goat, cattle, horse, bison, camel, pig, and deer (10-13). However, horse can serve as the potential intermediate host of these parasites and can be infected following ingestion of sporulated oocysts via contaminated feed or water, as well as via vertical transmission from mother to fetus through the placenta, which is an alternative route (14,
15). Both parasites are related to Coccidia, which is reported to cause encephalitis in horses (7). Toxoplasmosis is one of the most common parasitic zoonoses worldwide (16). Antibodies against T. gondii were detected in horses in the Czech Republic (17), Turkey $(18,19)$, Egypt (20), Sweden (21), and Switzerland (22). Toxoplasmosis is a common infection that rarely evolves to clinical disease (23), but may cause fever, ataxia, retinal degeneration, abortion, and severe encephalomyelitis (24).

$N$. caninum and $N$. hughesi were first described in dogs in Norway in 1984 in the brain and spinal cord of an adult horse in California, USA, respectively $(25,26)$. In 1990, the first serological evidence of $N$. caninum infection in a horse was described (27). Antibodies against Neospora $s p$. in equine populations have been reported in many parts of the world such as the United States (28), South Korea (29) Iran (30), and Brazil (31). In Europe, antibodies against $N$. caninum have been reported in horses in France (32), Italy (33), Sweden (34), Turkey (35) and the

Copyright (C) 2015, Ahvaz Jundishapur University of Medical Sciences. This is an open-access article distributed under the terms of the Creative Commons Attribution-NonCommercial 4.0 International License (http://creativecommons.org/licenses/by-nc/4.0/) which permits copy and redistribute the material just in noncommercial usages, provided the original work is properly cited. 
Tavalla $M$ et al.

Czech Republic (36). Horses can be infected by N. caninum and N. hughesi. Although exposure to Neospora spp. in horses seems to be common, clinical diseases are rare. The clinical disease is characterized by abortion, neonatal diseases, and neurological findings of severe encephalomyelitis (14). N. caninum and N. hughesi are related to abortions and neurological diseases in horses (31).

\section{Objectives}

Few data has been reported about the prevalence of T. gondii and N. caninum in Arab horses in Iran. The current research was conducted to investigate the seroprevalence of T. gondii and Neospora spp. infections among Arab horses, the most popular horse species in Khuzestan province, southwest of Iran, using modified agglutination test (MAT).

\section{Materials and Methods}

\subsection{Study Area}

The study area, Khuzestan province, covers approximately $65000 \mathrm{~km}^{2}$ and is located in southwest of Iran $\left(31^{\circ} 3^{-} \mathrm{N}, 48^{\circ} 7^{-} \mathrm{E}\right)$ (Figure 1). The climate of this area is generally hot and occasionally humid. Summertime temperatures routinely exceed $50^{\circ} \mathrm{C}$. Khuzestan province is known to master the hottest temperatures on record for a populated city anywhere in the world.

\subsection{Collection of Sera}

From October 2009 to March 2011, blood samples (5 to 10 $\mathrm{mL}$ ) were collected from jugular veins of 235 Arab horses of different ages and sexes. The samples were from 12 cities (Table 1) of Khuzestan province, southwest of Iran (Figure 1). According to the information taken from owners and the physical examinations performed by veterinarians on age and gender of horses, they were categorized into three age groups ( $\leq 2,2-10$, and $\geq 10$ years old). The blood samples were centrifuged 10 minutes at $3000 \mathrm{rpm}$ and serum was removed and stored at $-20^{\circ} \mathrm{C}$ until used.

\subsection{Parasites}

The T. gondii and $N$. caninum antigens used in MAT and N-MAT were prepared from the RH strain of T. gondii and the NC-1 strain of N. caninum tachyzoites, harvested from cells grown in mice in the Pasteur Institute of Tehran and the Razi Institute of Shiraz, Iran, respectively.

\subsection{Toxoplasma gondii Serology}

T. gondii antibodies were investigated using modified agglutination test, as described by Desmonts and Remington (37) and Dubey and Desmonts (38). The sera were diluted two folds (1:20 to 1:320) with phosphate buffered saline containing $0.2 \mathrm{M}$ 2-mercaptoethanol and $50 \mu \mathrm{L}$ of each dilution was put in a well of 96 U-bottom ELISA plates. Thereafter, $50 \mu \mathrm{L}$ of the whole formalin-preserved T. gondii tachyzoites were added to each serum dilution. The wells were then mixed thoroughly by pipetting up and down several times, covered, and then incubated at $37^{\circ} \mathrm{C}$ overnight. The test was considered positive when a layer of agglutinated parasites was formed in wells at dilutions of 1:20 or higher. Positive and negative controls were included in each test.

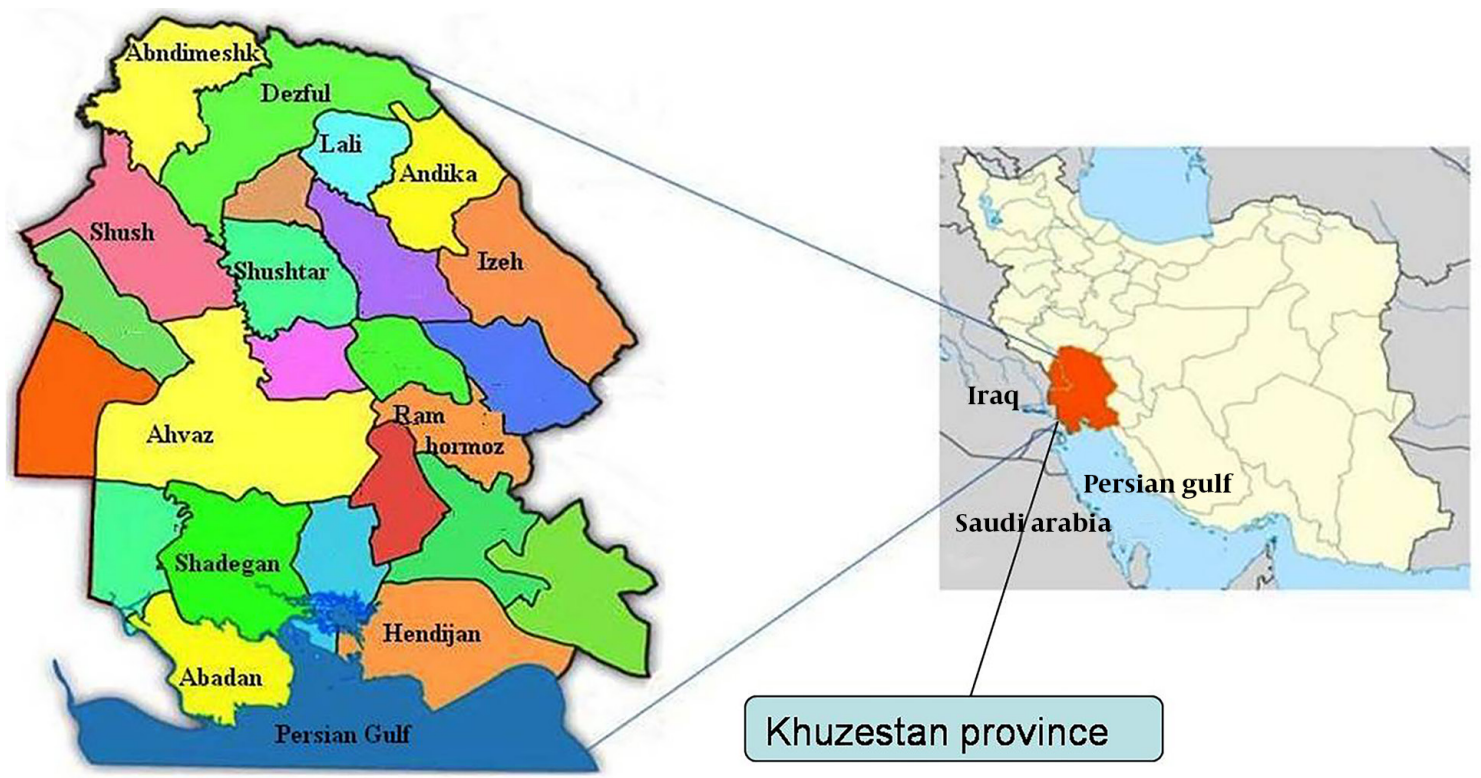

Khuzestan is highlighted with green. Cities of this province are distinguished by colures. The map of Khuzestan province by Uwe Dering highlighted by Dr. Blofeld. 
Tavalla $M$ et al.

\subsection{Neospora spp. Serology}

The N-MAT was used for detection of antibodies to Neospora spp. in horses, described by Romand et al. (39), which is very similar to MAT which is used for detection of toxoplasmosis in sera, except that Neospora tachyzoites were used as antigens. Briefly, the sera were diluted with phosphate buffer saline $(\mathrm{pH}=7.2)$ containing 2-Mercaptoethanol (2-ME) and screened with 1:40 and 1:80 dilutions. Positive sera at 1:80 dilutions were subsequently submitted to serial dilutions (1:160 to 1:640) (29).

\subsection{Statistical Analysis}

Differences in antibody prevalence of horses infected with $T$. gondii and Neospora spp. with regard to gender, age and geographical regions were analyzed using chisquare test and were calculated with SPSS (version 16.0). P value $<0.05$ was considered statistically significant.

\section{Results}

All the equines remained clinically normal and there was no evidence of abortion. The serological results are summarized in Tables 1, 2 and 3. The horses' sera were collected from different cities of Khuzestan province (Table
1). Statistical analysis showed that some factors like age affected the prevalence of T. gondii infection. In this study, we divided all the horses into three groups based on age, to 53 ( $\leq 2$ years old), 121 (2-10 years old), and 61 ( $\geq 10$ years old) horses. The $T$. gondii seroprevalence in adult horses ( $\geq 10$ years old) was significantly higher than other age groups (63\%: 38/61). The results showed that T. gondii seroprevalence in horses increased with age. Toxoplasma antibody with MAT in horses in the age group of 2-10 was $49 \%$ (59/114) and was 33\% in the age group of $\leq 2$ (17/53). However, we could not find any correlation regarding antibodies and age between the three groups. We found 31 (13/2\%) samples that showed antibodies for both of these parasites in at least the 1:20 titer.

\subsection{Toxoplasma gondii}

Antibodies to T. gondii were detected in 114 (48.5\%) Arab horses. The majority of the positive sera had titers $\leq 1: 20$ (Table 2). The seroprevalence in horses varied from $1.8 \%$ to $28 \%$ between regions. No differences in seroprevalence were found between male and female horses. Antibodies to T. gondii were found in 84 (35.8\%) of 235 horses with titers of $1: 20,19(8.1 \%)$ with titers $1: 40,4(1.7 \%)$ with titers of $1: 80,4(1.7 \%)$ with titers of $1: 160$, and $3(1.3 \%)$ with titers of 1:320. MAT was repeated twice in this step.

Table 1. The Number of Samples From Different Sites in Khuzestan Province and Their Serological Status Against Toxoplasma gondii and Neospora caninum

\begin{tabular}{|c|c|c|c|c|c|c|c|}
\hline \multirow[t]{2}{*}{ City } & \multirow[t]{2}{*}{ Samples, No. } & \multirow[t]{2}{*}{ Males, No. } & \multirow[t]{2}{*}{ Females, No. } & \multicolumn{2}{|c|}{ T. gondii (+) } & \multicolumn{2}{|c|}{ Neospora spp. (+) } \\
\hline & & & & Male & Female & Male & Female \\
\hline Abadan & 31 & 16 & 15 & 4 & 7 & 2 & 2 \\
\hline Ahvaz & 58 & 27 & 31 & 21 & 12 & 7 & 11 \\
\hline Ramhormoz & 15 & 9 & 6 & 3 & 5 & 1 & 1 \\
\hline Shush & 18 & 9 & 9 & 4 & 2 & 1 & 4 \\
\hline Shushtar & 15 & 10 & 5 & 4 & 5 & 2 & 2 \\
\hline Dezfol & 24 & 13 & 11 & 6 & 4 & 1 & 2 \\
\hline Lali & 10 & 6 & 4 & 2 & 1 & - & 1 \\
\hline Andilka & 10 & 3 & 7 & 3 & 1 & 1 & 1 \\
\hline Andimeshk & 15 & 7 & 8 & 3 & 3 & - & - \\
\hline Hendijan & 10 & 6 & 4 & 3 & 4 & 1 & - \\
\hline Izeh & 13 & 8 & 5 & 5 & 3 & 2 & - \\
\hline Schadegan & 16 & 8 & 8 & 5 & 4 & 2 & 3 \\
\hline Total & 235 & 122 & 113 & 63 & 51 & 20 & 27 \\
\hline
\end{tabular}

Table 2. Modified Agglutination Test Titers for T. gondii in Sera From 235 Arab Horses of Khuzestan Province

\begin{tabular}{lccccc}
\hline & \multicolumn{5}{c}{ Titers } \\
\cline { 2 - 5 } & $\mathbf{1 : 2 0}$ & $\mathbf{1 : 4 0}$ & $\mathbf{1 : 8 0}$ & $\mathbf{1 : 1 6 0}$ & $\mathbf{1 : 3 2 0}$ \\
\hline Male & $51 / 122(42)$ & $7 / 122(5.8)$ & $2 / 122(1.7)$ & $1 / 122(0.8)$ & $2 / 122(1.7)$ \\
Female & $33 / 113(30)$ & $12 / 113(10.7)$ & $2 / 113(1.8)$ & $3 / 113(2.7)$ & $1 / 113(0.9)$ \\
Total & $84 / 235(35.8)$ & $19 / 235(8.1)$ & $4 / 235(1.7)$ & $4 / 235(1.7)$ & $3 / 235(1.3)$ \\
\hline
\end{tabular}

${ }^{\text {a }}$ Data are presented as No. (\%)

Jundishapur J Microbiol. 2015;8(3):e14939 
Table 3. Direct Agglutination Test to Neospora spp. in Sera From 235 Arab Horses in Khuzestan Province a

\begin{tabular}{lccc}
\hline & \multicolumn{3}{c}{ Titers } \\
\cline { 2 - 4 } & $\mathbf{1 : 4 0}$ & $\mathbf{1 : 8 0}$ & $\mathbf{1 : 1 6 0}$ \\
\hline Male & $17 / 122(14)$ & $2 / 122(1.7)$ & $1 / 122(0.8)$ \\
Female & $22 / 113(20)$ & $3 / 113(2.7)$ & $2 / 113(1.8)$ \\
Total & $39 / 235(16.6)$ & $5 / 235(2.2)$ & $3 / 235(1.3)$ \\
\hline
\end{tabular}

${ }^{\text {a }}$ Data are presented as No.(\%)

\subsection{Neospora spp.}

Antibodies to Neospora spp. were detected in 47 (20\%) among Arab horses. Sera were examined by the developed Neospora agglutination test (NAT) as described by Romand et al. (39) NAT is similar to MAT for T. gondii except that tachyzoites of Neospora spp. are used instead T. gondii tachyzoites. Antibody titers to Neospora spp. in examined horses are shown in Table 3. At 1:40 dilution, the prevalence of antibodies to Neospora spp. was $14 \%$ for males and 20\% for females, while at 1:80 and 1:160 dilutions prevalence was $1.7 \%$ and $0.8 \%$ for males and $2.7 \%$ and $1.8 \%$ for females respectively.

\section{Discussion}

This is the first report of T. gondii and Neospora spp. infections in Arab horses in southwest of Iran. Results of this investigation indicated that 114 (48.6\%) of 235 Arab horses had been exposed to T. gondii and antibodies to Neospora spp. were detected in 47 (20.5\%) of them. MAT is considered as one of the highly specific and sensitive tests for detection of T. gondii and Neospora spp. in animals, especially in horses $(23,40)$. Although antibodies to $T$. gondii have been reported in horses by MAT, ELISA or IFAT from many countries, there is no clear evidence that this protozoan causes clinical diseases in horses (23).We did not find any significant differences between the seroprevalence of T. gondii and Neospora spp. and horses gender. Dubey et al. the first time detected tachyzoites of $N$. caninum in a fetus lung (27) and $N$. hughesi tachyzoites were isolated from an adult horse in the US (8). Horizontal transmission of Neospora spp. in horses appears to be a major mode of transmission (41). Because of serological cross reactivity between $N$. caninum and N. hughesi, we could not confirm which species of Neospora infected Arab horses using MAT. The seroprevalence of T. gondii in older horses indicated more prevalence rates, which was in agreement with Boughattas's study in Tunisia (42). In a recent Iranian survey in northeast of Iran on Neospora in horses, they detected Neospora antibodies in $30 \%$ of horses using N-MAT (43). The serological results of this study indicated that 47 of 235 (20\%) horses were exposed to Neospora spp. which was comparable to those reported from the northwest, north, south and west of Iran as $28 \%, 30 \%, 32 \%$ and $40.8 \%$, respectively $(30,43-45)$.
Our results were comparable to those reported from the US, France and Italy $(27,33,46)$. According to hajialilo's study in Qazvin, Iran, 71.2\% of sport horses were seropositive for T. gondii (47).

The prevalence of Neospora spp. antibodies in cattle in the southeast of Iran was $12.6 \%$ (48) and in water buffaloes in the southwest of Iran it was 37\% (49). This results imply that exposure to this parasite is common in south of Iran. Dogs could be one of the main definitive host in this region. According to the study of Hosseininejad et al. the prevalence of $N$. caninum in dogs from west and central parts of Iran was $26.8 \%$ (50). Another study in west of Iran (Hamedan province) indicated that the prevalence of $N$ caninum in dogs was 27\% (51). Further research on the epidemiological and molecular evidence for identification of Neospora strains is required. This study was the first investigation on T. gondii and Neospora spp. in Arab horses of Khuzestan province, Iran, and indicates that there is exposure to these parasites in this region. Therefore, designing control strategies including restriction of the existent stray cats and dogs in farm hoses as well as follow up and treatment of the owned dogs is recommended and further studies such as molecular and sequencing methods are needed to distinguish N. caninum from N. hughesi.

\section{Acknowledgements}

This study was conducted using personal financial sources. We are very grateful to Dr. Mohammad M. Namavari from RAZI Vaccine and Serum Research Institute, Shiraz, Iran, whose cooperation is deeply appreciated, especially for providing the Neospora spp. tachyzoites.

\section{Authors' Contributions}

Tavalla Mehdi: study design, study execution, data analysis and interpretation, and preparation of the manuscript. Sabaghan Mohammad: data collection, study execution, and preparation of the manuscript. Abdizadeh Rahman: study execution and preparation of the manuscript. Shahram khademvatan: data analysis and interpretation and preparation of the manuscript. Rafiei Abdollah: preparation of the manuscript.

\section{References}

1. Dubey JP. Toxoplasmosis of animals and humans. 2nd edBoca Raton,Florida, New York: CRC press; 2010.

2. Goodswen SJ, Kennedy PJ, Ellis JT. A review of the infection, genetics, and evolution of Neospora caninum: from the past to the present. Infect Genet Evol. 2013;13:133-50.

3. Sedlak K, Bartova E. Seroprevalences of antibodies to Neospora caninum and Toxoplasma gondii in zoo animals. Vet Parasitol. 2006;136(3-4):223-31.

4. De Craeye S, Speybroeck N, Ajzenberg D, Darde ML, Collinet F, Tavernier P, et al. Toxoplasma gondii and Neospora caninum in wildlife: common parasites in Belgian foxes and Cervidae? Vet Parasitol. 2011;178(1-2):64-9.

5. Kamga-Waladjo AR, Gbati OB, Kone P, Lapo RA, Dombou E, Chatagnon G, et al. Neospora caninum and Toxoplasma gondii in lion 
Tavalla $M$ et al.

(Panthera leo) from Senegal, West Africa. Asian J Anim Vet Adv. 2009;4(6):346-9.

6. Wiengcharoen J, Nokkaew W, Prasithpon S, Prasomtong P, Sukthana Y. Neospora caninum and Toxoplasma gondii Antibodies in Captive Elephants (Elephaus maximus indicus) in Kanchanaburi Province. Thai J Vet Med. 2012;42(2):235-40.

7. Dubey JP. History of the discovery of the life cycle of Toxoplasma gondii. Int J Parasitol. 2009;39(8):877-82.

8. McAllister MM, Dubey JP, Lindsay DS, Jolley WR, Wills RA, McGuire AM. Rapid communication: Dogs are definitive hosts of Neospora caninum. Int J Parasitol.1998;28(9):1473-9.

9. Dubey JP, Schares G, Ortega-Mora LM. Epidemiology and control of neosporosis and Neospora caninum. Clin Microbiol Rev. 2007;20(2):323-67.

10. Dubey JP. Review of Neospora caninum and neosporosis in animals. Korean J Parasitol. 2003;41(1):1-16.

11. Bartova E, Sedlak K. Seroprevalence of Toxoplasma gondii and Neospora caninum in slaughtered pigs in the Czech Republic. Parasitology. 2011;138(11):1369-71.

12. Hamidinejat H, Ghorbanpour M, Rasooli A, Nouri M, Hekmatimoghaddam S, Namavari MM, et al. Occurrence of anti-Toxoplasma gondii and Neospora caninum antibodies in camels (Camelus dromedarius) in the center of Iran. Turkish J Vet Anim Sci. 2013;37(3):277-81.

13. Meng QL, Qiao J, Wang WS, Chen CF, Zhang ZC, Cai KJ, et al. Seroprevalence of Toxoplasma gondii and Neospora caninum in Tarim Red Deer (Cervus elaphus yarkandensis) from Xinjiang Province, Northwest China. J Anim Vet Adv. 2012.

14. Lindsay DS. Neosporosis: an emerging protozoal disease of horses. Equine Vet J. 2001;33(2):116-8.

15. Tassi P. Toxoplasma gondii infection in horses. A review. Parassitologia. 2007;49(1-2):7-15.

16. Akca A, Babur C, Arslan MO, Gicik Y, Kara M, Kilic S. Prevalence of antibodies to Toxoplasma gondii in horses in the province of Kars, Turkey. Veterinarni Medicina-UZPI (Czech Republic). 2004;49(1).

17. Hejlicek K, Literak I. Prevalence of antibodies to Toxoplasma gondii in horses in the Czech Republic. Acta Parasitol. 1994; 39(4):217-9.

18. Babur C, Cakmak A, Biyikoglu G, Piskin FC. The detection of antiToxoplasma gondii antibodies by Sabin Feldman dye test in horses which were slaughtered to feed the wild animals in the zoo of the Ataturk Forest Farm. Acta Parasitol Turcica. 1998;22:174-6.

19. Gazyagci S, Macun HC, Babur C. Investigation of seroprevalance of toxoplasmosis in mares and stallions in Ankara province, Turkey. Iranian J Vet Res. 2011;12(4):354-6.

20. Shaapan RM, Abo-ElMaaty AM, El-Razik KAA, El-Hafez SMA. PCR and serological assays for detection of Toxoplasma gondii infection in sport horses in Cairo, Egypt. Asian J Anim Vet Adv 2012;7(2):158-65.

21. Uggla A, Mattson S, Juntti N. Prevalence of antibodies to Toxoplasma gondii in cats, dogs and horses in Sweden. Acta Vet Scand. 1990;31(2):219-22.

22. Wyss R, Sager H, Muller N, Inderbitzin F, Konig M, Audige L, et al. Original contributions-Distribution of Toxoplasma gondii and Neospora caninum under aspects of meat hygiene. Schweiz Arch Tierh. 2000;142(3).

23. Dubey J, Beattie. C. . Toxoplasmosis of animals and man.: CRC Press, Inc.; 1988.

24. Guclu Z, Karaer Z, Babur C, Kilic S. Investigation of Toxoplasma gondii antibodies in sport horses bred in Ankara province. Turkiye Parazitol Derg. 2007;31(4):264-7.

25. Bjerkas I, Mohn SF, Presthus J. Unidentified cyst-forming sporozoon causing encephalomyelitis and myositis in dogs. Z Parasitenkd. 1984;70(2):271-4.

26. Marsh AE, Barr BC, Packham AE, Conrad PA. Description of a new Neospora species (Protozoa: Apicomplexa: Sarcocystidae). J Parasitol.1998;84(5):983-91.

27. DubeyJP, Porterfield ML. Neospora caninum (Apicomplexa) in an aborted equine fetus. J Parasitol.1990;76(5):732-4.

28. Dubey JP, Romand S, Thulliez P, Kwok OC, Shen SK, Gamble HR. Prevalence of antibodies to Neospora caninum in horses in North America. J Parasitol. 1999;85(5):968-9.
29. Gupta GD, Lakritz J, Kim JH, Kim DY, Kim JK, Marsh AE. Seroprevalence of Neospora, Toxoplasma gondii and Sarcocystis neurona antibodies in horses from Jeju island, South Korea. Vet Parasitol. 2002;106(3):193-201.

30. Gharekhani J, Tavoosidana GR, Naderisefat GR. Seroprevalence of Neospora infection in horses and donkeys in Hamedan province, Western Iran. Vet World. 2013;6(9):620-2.

31. Villalobos EM, Furman KE, Lara Mdo C, Cunha EM, Finger MA Busch AP, et al. Detection of Neospora sp. antibodies in cart horses from urban areas of Curitiba, Southern Brazil. Rev Bras Parasitol Vet. 2012;21(1):68-70.

32. Pitel PH, Romand S, Pronost S, Foucher N, Gargala G, Maillard K, et al. Investigation of Neospora sp. antibodies in aborted mares from Normandy, France. Vet Parasitol. 2003;118(1-2):1-6.

33. Ciaramella P, Corona M, Cortese L, Piantedosi D, Santoro D, Di Loria A, et al. Seroprevalence of Neospora spp. in asymptomatic horses in Italy. Vet Parasitol. 2004;123(1-2):11-5.

34. Jakubek EB, Lunden A, Uggla A. Seroprevalences of Toxoplasma gondii and Neospora sp. infections in Swedish horses. Vet Parasitol. 2006;138(3-4):194-9.

35. Kilbas ZG, Adanir R, Avcioglu H. Seroprevalence of Neospora caninum in racehorses in Ankara, Turkey. Acta Parasitol. 2008;53(3):315-6

36. Bartova E, Sedlak K, Syrova M, Literak I. Neospora spp. and Toxoplasma gondii antibodies in horses in the Czech Republic. Parasitol Res. 2010;107(4):783-5.

37. Desmonts G, Remington JS. Direct agglutination test for diagnosis of Toxoplasma infection: method for increasing sensitivity and specificity. J Clin Microbiol.1980;11(6):562-8.

38. Dubey JP, Desmonts G. Serological responses of equids fed Toxoplasma gondii oocysts. Equine Vet J.1987;19(4):337-9.

39. Romand S, Thulliez P, Dubey JP. Direct agglutination test for serologic diagnosis of Neospora caninum infection. Parasitol Res. 1998;84(1):50-3.

40. Dubey JP, Thulliez P, Weigel RM, Andrews CD, Lind P, Powell EC. Sensitivity and specificity of various serologic tests for detection of Toxoplasma gondii infection in naturally infected sows. Am J Vet Res. 1995;56(8):1030-6.

41. Corbellini LG, Smith DR, Pescador CA, Schmitz M, Correa A, Steffen DJ, et al. Herd-level risk factors for Neospora caninum seroprevalence in dairy farms in southern Brazil. Prev Vet Med. 2006;74(2-3):130-41.

42. Boughattas S, Bergaoui R, Essid R, Aoun K, Bouratbine A. Seroprevalence of Toxoplasma gondii infection among horses in Tunisia. Parasit Vectors. 2011;4:218.

43. Hosseini M, Moraveji M, Tahamtan Y, Rahimian A, Mohammad G, Namavari M. Seroprevalence of Neospora spp. in Horses in North East of Iran. Iran J Parasitol. 2011;6(2):64-8

44. Moraveji M, Hosseini MH, Amrabadi O, Rahimian A, Namazi F, Namavari M. Seroprevalence of Neospora spp. in horses in South of Iran. Trop Biomed. 2011;28(3):514-7.

45. Garedaghi Y. Seroepidemiology of Neospora sp. in Horses in EastAzerbaijan Province of Iran. J Anim Vet Adv. 2012;11(4):480-2.

46. Pitel PH, Pronost S, Romand S, Thulliez P, Fortier G, Ballet JJ. Prevalence of antibodies to Neospora caninum in horses in France. Equine Vet J. 2001;33(2):205-7.

47. Hajialilo E, Ziaali N, Harandi MF, Saraei M, Hajialilo M. Prevalence of anti-Toxoplasma gondii antibodies in sport horses from Qazvin, Iran. Trop Anim Health Prod. 2010;42(7):1321-2.

48. Reza Nourollahi Fard S, Khalili M, Aminzadeh A. Prevalence of antibodies to Neospora caninum in cattle in Kerman province, South East Iran. Vet Arhiv. 2008;78(3):253-9.

49. Hajikolaei MR, Goraninejad S, Hamidinejat H, Ghorbanpour M, Paryab R. Occurrence of Neospora caninum antibodies in water buffaloes (Bubalus bubalis) from the south-western region of Iran. Bull Vet Inst Pulawy. 2007;51(2):233.

50. Hosseininejad M, Hosseini F. Seroprevalence of Neospora caninum and Toxoplasma gondii infection in dogs from west and central parts of Iran using two indirect ELISA tests and assessment of associate risk factors. Iran J Vet Res. 2011;121:46.

51. Gharekhani J, Tavoosidana G, Akbarein H. Serological study of Neospora caninum infection in dogs and cattle from west of Iran. Comp Clin Path. 2014;23(5):1203-7. 